\title{
Testing Ecocentric and Anthropocentric Attitudes toward the Sustainable Development (EAATSD) Scale with Bachelor Students
}

\author{
Helen Kopnina ${ }^{1 *}$, Andreea Cocis $^{2}$ \\ ${ }^{1}$ Leiden University, The Netherlands \\ ${ }^{2}$ The Hague University of Applied Science, The Netherlands \\ *Corresponding Author: alenka1973@yahoo.com
}

Citation: Kopnina, H. and Cocis, A. (2017). Testing Ecocentric and Anthropocentric Attitudes toward the Sustainable Development (EAATSD) Scale with Bachelor Students. European Journal of Sociology and Anthropology, 2(1), 2.

doi: $10.20897 /$ ejsa.201702

Published: July 22, 2017

\begin{abstract}
The Ecocentric and Anthropocentric Attitudes toward the Sustainable Development (EAATSD) scale is adapted from other scales measuring environmental concern with the aim of specifically targeting the subject of sustainable development. This scale was tested with three groups of students, those of International Business and Management Studies, and of Sustainable Business, both at The Hague University of Applied Science; and students of Environment and Development at Leiden University College. It was hypothesized that students who chose elective courses concerned with sustainability will be more ecocentric than those from a general business course. Analysis of the findings demonstrates however that while there are individual differences in attitudes between the students within the course, there are no significant differences between the students in different courses. This suggests that anthropocentric and ecocentric values are independent of the students' chosen course, and that students that follow sustainability course are not more ecocentric.
\end{abstract}

Keywords: anthropocentrism, ecocentrism, environmental attitudes, sustainable development

\section{INTRODUCTION}

\section{Anthropocentric and Ecocentric Values}

While there is some debate about the precise definition of ecocentrism and anthropocentrism, ecocentric orientations broadly encompass concern for the ecosystems and their elements, and anthropocentric orientations are focused on human welfare. The land ethics (Leopold 1949), ecological justice (e.g. Baxter 2005), animal rights (e.g. Singer 1977), and deep ecology (e.g. Naess 1973) are usually associated with as 'ecocentric positions'. Collectively, and with some variations, these positions argue that that nature has an intrinsic value or value independent of human interests and that the integrity of ecosystems needs to be recognized as foundational for environmental sustainability. By contrast, shallow ecology (e.g. Naess 1973), environmental justice associated with social justice (Gleeson and Low 1999) and pragmatic environmental ethics (Light 1996) are associated with anthropocentric environmental values.

While pragmatist environmental ethics postulates that the intrinsic values have little practical value (Norton 1984; Light 1996), ecocentric ethics argued that the intrinsic value discourse is to environmental policy what the human rights discourse has been to social reform movements (Vucetich and Nelson 2013). Basically, it is argued that without acknowledging the intrinsic value, the rights and welfare of nonhuman nature that are not functionally useful to human welfare are likely to be continuously ignored (Eckersley 2004; Miller at al 2013). Essentially, 
anthropocentric orientations make a portion of biological diversity expendable and ignore animal welfare concerns, because no negative side effects for people ensue (Cafaro 2015; Shoreman-Ouimet and Kopnina 2016).

These value orientations become particularly salient in cases when sustainability is discussed. Sustainability is often associated with sustainable development and the triple objectives of successfully balancing the 'people, profit and planet' (Washington 2015). While social and economic sustainability is associated with anthropocentric values, ecological sustainability is related to ecocentric values, but can also be 'mixed' as sometimes human self-interest and environmental concern overlap (Norton 1984).

The concept of sustainable development is not without its critics. Critics have emphasized that promoting economic development is not likely to address the root causes of poverty, which are related to the transnational politics of competition in global markets and industrial capital, and is likely to exacerbate ecological crisis by increasing global consumption (Rees 2010; Washington 2015). Simultaneously, sustainable development rhetoric tends to privilege human welfare over concerns with the environment (Rolston 2015; Shoreman-Ouimet and Kopnina 2016). This prioritizing of economic objectives not only undermines human resource base in the long term, but also negates the very chance of other species' evolutionary unfolding (Crist 2012; Cafaro 2015).

Interdisciplinary social scientists, which study societal and psychological manifestations and motivation behind environmental thought and action, have exposed anthropocentrism as one of the main drivers of the current ecological crisis (e.g. Stern and Dietz 1994; Stern 2000; Dunlap 2008; Shoreman-Ouimet and Kopnina 2016). The studies of anthropocentric and ecocentric values indicate that people with ecocentric orientation are more likely to act upon their values in order to protect the environment than those with anthropocentric orientations (Thompson and Barton 1994; Kortenkamp and Moore 2001; Kopnina 2015). Commonly, ecocentric orientation leads to sacrifice for the sake of environment rather than quality-of-life solutions to environmental problems (Kaplan 2000). Gifford (2011), for example, notes that although many individuals are engaged in some ameliorative action to address climate change they are hindered by a number of psychological barriers, which ideological world views that preclude pro-environmental attitudes and behavior.

There is a wide range of measurements of environmental attitudes, values and behavior, many of which are listed on the website of Conservation Psychology (http://www.conpsychmeasures.com/). The Ecocentric and Anthropocentric Attitudes toward the Sustainable Development (EAATSD) scale is based on Thompson and Barton's (1994) Ecocentric and Anthropocentric Attitudes towards the Environment (EAATE) scale, measuring ecocentrism, anthropocentrism and environmental apathy ${ }^{1}$. The EAATSD scale consists of 22 items that measured ecocentrism, anthropocentrism and environmental apathy in relation to sustainable development ${ }^{2}$. EAATSD scale was used in studies related to environmental education (EE) and education for sustainable development (ESD) (e.g. Wolbring and Burke 2013; Kanyimba et al 2014; Besong and Holland 2015; Cocks and Simpson 2015), teachers' conceptions of the environment (Quinn et al 2015) and other studies that apply environmental values in educational contexts.

In this article, the EAATSD scale will be used to test whether Bachelor students who choose to enroll into sustainability-related courses exhibit more ecocentric values than the students enrolled in regular business courses. This article aims to discuss sustainability in relation to anthropocentric an ecocentric values and draw recommendations in relation to environmental education (EE) and education for sustainable development (ESD).

\section{MATERIALS AND METHODS}

The pilot study conducted in 2013 compared two groups of the Bachelor program students of International Business and Management Studies (IBMS) from The Hague University of Applied Science (HHS). The pilot compared the scores of the IBMS students from different business-oriented minors (Finance, Areas in Marketing, and Branding), with the group that chose Sustainable Business (SB) minor. Based on the results of the pilot study,

\footnotetext{
1 Thompson and Barton (1994)'s study was conducted at the Logan International Airport in Boston. One hundred and twenty-nine respondents (58 females and 51 male) completed the questionnaires, ranging in age from 19 to 82. In study 1, Cronbach's alpha ranged from .58 to .83 (Ecocentrism = .63; Anthropocentrism = .58; and Environmental Apathy $=.83$ ). In study 2, Cronbach's alpha ranged from .67 to .78 (Ecocentrism $=.78$; Anthropocentrism $=.67$; and Environmental Apathy $=.82$ ).

${ }^{2}$ Some questions could be classified as concerned with lifestyle choices, others with intrinsic values, yet others with conservation - see appendix 1 'Mind map'. Questions 1, 4, 9, 12, 17, 19, 21, 22 are ecocentric. Questions 5, $6,7,10,14,16$ are apathetic (indifferent to environmental problems) and questions 2, 3, 8, 11, 13, 15, 18, 20 are anthropocentric (see the questions in the appendix and detailed description in Kopnina 2013). In this study below we have combined anthropocentric and apathetic statements (as apathy was related to environment and not to social aspects), thus leading to this division in statements: Ecocentric: 1, 4, 9, 12, 17, 19, 21, 22; Anthropocentric 2, 3, 5, 6, 7, 8, 10, 11, 13, 14, 15, 16, 18, 20. See appendix 2 'Scale'.
} 
the research conducted in 2016 tested whether ecocentric orientation corresponds with the choice of a sustainability-related elective course. This confirmation study involved both IBMS students and liberal arts students from Leiden University College (LUC) in The Netherlands. The actual content of the course is not discussed here, as the authors were particularly interested in the zero-measurement and the question of whether the students who have chosen to study sustainable business (SB) or environment and development (E\&D) had more ecocentric orientation than students in the general business course (IBMS). The EAATSD survey was administered at the start of the courses to test the hypothesis that the students who have chosen the sustainabilityrelated courses were more ecocentric than students from a regular IBMS business course. Students were asked to rate a degree of agreement with the items on the scale from 1 to 5 ( 1 is strongly disagree, 2 disagree, 3 neither agree nor disagree, 4 agree and 5 strongly agree). The analysis includes calculations of frequency, mean, standard deviation and Chi-square, using simple or cross tabs. Completion of the scale by the students was accompanied by the in-class discussion about perceptions and attitudes toward relationship of humans to nature.

\section{Setting and Sampling Technique}

All student populations consisted of international students (with the largest group of Dutch nationals) in their second and third year of study. The students at the business school at HHS and LUC were all between the ages of 20 and 24, with the roughly 50/50 male and female ratio. The ages and gender were not recorded as we were primarily interested in the differences between students' values in different courses.

Random sampling was used to provide an unbiased statistics which has the characteristic that as the sample size increases, the statistics from the sample approaches the true values of the population. A second advantage is that the statistical analysis related to sample distributions, hypothesis testing, and sample size determinations assume that the sample is a simple random sample.

For the pilot study in 2013, the two groups selected were the general IBMS students following various minors (control group) and an elected minor of Sustainable Business (SB). The confidence level was chosen as 95\% $(a=0.05)$, and our confidence interval of 13, determining the needed sample of 47.
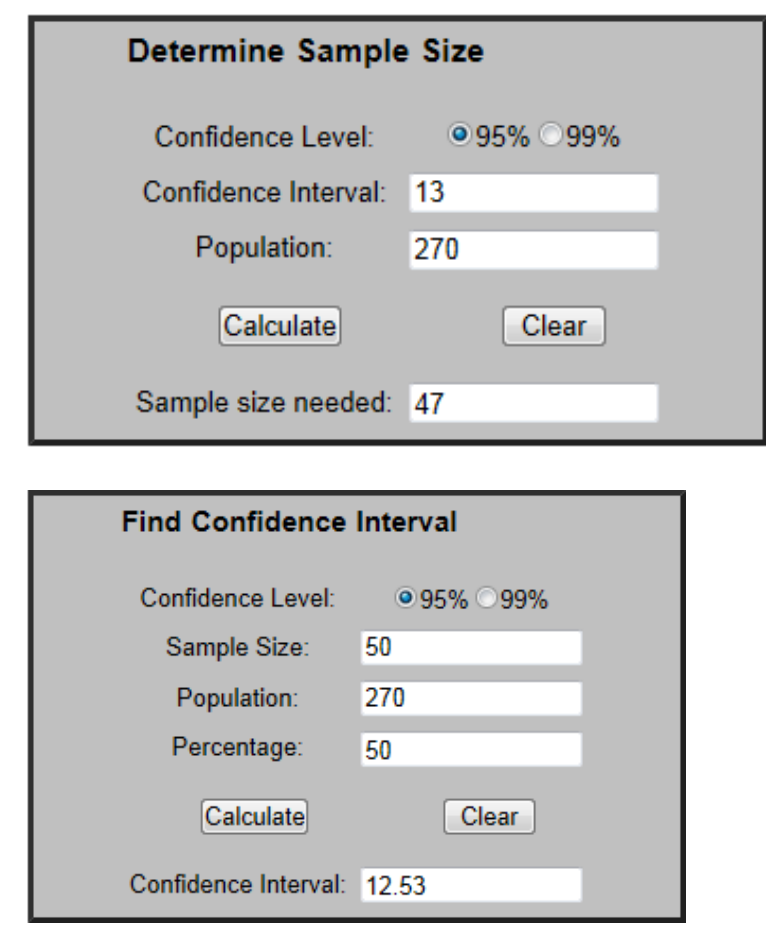

Of the total 270 second year students at IBMS, forty nine (49) students were selected from different elective minors to ensure heterogeneity of responses. Of these students, thirty three (33) responders chose SB minor and sixteen (16) responders chose other minors.

For the confirmation study, the EAATSD questionnaires have been completed between January and March 2016. This case study was drawn from two student populations, all of international Bachelor level students:

1. International Business Management Studies (IBMS) second years students of The Hague University of Applied Science (HHS) who followed required course Business Ethics and Sustainability (BE\&S). The sample consisted of students with ages varying from 20 to 24 , with a roughly equal female-male ratio. This group corresponded to a general heterogeneous group of IBMS students from the pilot study. BE\&S there were 42 participating students. 
2. Environment and Development $(\mathbf{E} \& \mathbf{D})$, the elective second and third year course at Leiden University College (LUC). The sample consisted of students with ages varying from 22 to 24, with 10 males and 8 females. In E\&D there were 18 participating students.

\section{THEORY/CALCULATION}

\section{Data Analysis Procedures}

A codebook in Microsoft Excel was used and the data were entered into SPSS, enabling generation of bar chart, pie charts and histograms, as well as information about the mean, frequency of each scale, maximum and minimum value and standard deviation. SPSS analysis allowed comparative analysis within and between the groups.

\section{Results}

Shortly, the comparison of all three groups, the pilot group in 2013 and E\&D group in 2016 being both selfselected for sustainability-related courses, and BE\&S group from 2016 being a control group shows that the differences between ethical orientation between groups to be rather insignificant. However, there is a large variation within the groups - thus significant individual differences. The detailed results of the SPSS analysis can be found in the appendix.

Comparing the 2016 results with the pilot study, the means changed, demonstrating that the control group does make a difference in the study. Overall in all groups, the current results demonstrate that the ecocentric behavior is more present that the anthropocentric. For questions 1, 4, 9, 12, 17, 19, 21 and 22 the scores have an average of 3.67 for E\&D and 3.44 for BE\&S (control group), while the 2013 pilot study had averages of 3.45 and 3.24. The difference between the groups is not significant, indicating that the ecocentric values are present independent of the students' choice of course. At the same time, the control group has elevated the results for the 2016 study.

The standard deviations for both E\&D and BE\&S are elevated, with more than $99 \%$ over 0.5 , out of which more than $65 \%$ over 1, with 1.36363 as the highest deviation. For a better comparison, the same questions were combined as in the pilot study: 2 and 4,6 and 12,16 and 19, 3 and 9. Looking at the likelihood ratios*, the scores varied between 0.055 and 0.265 , meaning that the variables are independent. The only exception of a meaningful change in between the studies would be the cross tabulation between question 16 and 19. In this case, as the likelihood ratio is 0.018 . This means that it might be probable that the variables are related. Thus, there is no significant difference between the values of BE\&S and E\&D students.

The main findings of 2016 study indicate that the ecocentric and anthropocentric values can be found independently of the students' area of study. SPSS analysis revealed that in average the ecocentric behavior is slightly more common. Questions 1, 4, 9, 12, 17, 19, 20, 21 and 22 have a total mean of 3.51, clearly indicating that the students tend to be inclined towards the environmental values. In comparison, the questions with a focus on the anthropocentric behavior round up to a total mean of 2.63. The standard deviation varies for each question, while still remaining in the commonly accepted rule of three. For a deeper understanding, frequencies have been calculated for each of the questions.

Results confirm that the concerns about environmental issues are present in all groups (averages of ecocentric questions $77.96 \%$ for BE\&S and $82.65 \%$ for $\mathrm{E} \& \mathrm{D}$ ) with 65 to $90 \%$ of answers falling on the upper side of the scale. The intrinsic values of nature or individual animals are indicated by the high percentages, as well as the nature conservation ideas. Human welfare seems to be a less dominant reasoning behind any inclination towards the sustainable development, but there is a small difference was noticed between the E\&D students (42.24\%) and BE\&S students $(52.86 \%)$.

The in-class discussion in all classes has revealed that student perception of 'sustainability' is not necessarily linked to environment, but also to social and economic sustainability. The students in elective courses have chosen sustainability as a subject in order to address social justice, economic equality, and other subjects that they did not necessarily see as related to environmental integrity (for more discussion of qualitative analysis of student perceptions of sustainability, see Kopnina 2012a; Kopnina 2012b; Kopnina 2013; Kopnina and Blewitt 2014; Kopnina 2015; Kopnina 2016).

\section{Reflection on the study}

The hypothesis formed in this comparative study was that business students might be less ecocentric then environmental sustainability course students. However, the findings have revealed that both groups exhibit individual differences in environmental attitudes, but little difference between groups. Thus, ecocentric orientation does not necessarily correspond with the choice of course. Students from HHS and LU who choose the SB or E\&D courses prioritize anthropocentric concerns in more or less equal measure as other business students. Also, IBMS students exhibit individual differences in their ecocentric and anthropocentric orientations independent of 
the minor they follow. The score for students in sustainable business and other minors given is not large, as the difference of score between sustainable business and other minors was $2.4 \%$ both ecocentic and anthropocentric. On average it appears that all students tend to be more ecocentric, independent of the minor.

The cross tabs have revealed that there is no correlation between the ecocentric and anthropocentric values. The chi-square analysis performed on several combinations of the two types of questions revealed the independence of the variables. The assumption of the non-dependent variables is confirmed by looking at the likelihood ratios. Therefore it is right to conclude that the ecocentric and anthropocentric values are not related even if they are expressed. This is confirmed by in-class discussion in all classes that demonstrates that sustainability which involves concepts of economic growth are not necessarily perceived as contradictory to the concept of ecological integrity, and both general course and sustainability-course students can simultaneously exhibit both value orientations.

\section{DISCUSSION}

The relatively uniform results across different courses need to be related to a larger context of sustainability. As mentione din the introduction, sustainability rhetoric is intertwined with the notion of the triple objective of sustainable development (Bonnett 2003; Washington 2015). Yet, economic growth (profit) objective was noted to render the ecological integrity objective all but impossible given the fact that economic prosperity is currently associated with the global dissemination of unsustainable consumer culture (Crist 2012; Kopnina and Blewitt 2014; Rolston 2015). As Hansen and Wethal (2014) have emphasized, unsustainable production and consumption in developed countries is far from abating and developing countries are eager to emanate this 'progress' without serious reflection of what this means for the planet in the long term.

As Bonnett (2003) and Kopnina (2012a, 2012b, 2016) have noted, as currently practiced, much of ESD is concentrated on social and economic issues, concerned with equality and equity in distribution of environmental burdens and benefits. This so-called 'environmental justice' (Gleeson and Low 1999) is in fact associated with exclusive social justice and not with ecocentric values embodied in ecological justice, or justice between species (Baxter 2005).

Returning to the case study, the students who have chosen to take courses in sustainability are not necessarily 'self-selected' for ecocentric value orientations, as their altruism may be exclusively social (Stern 2000). This indicates a need to enhance ecocentric values associated with strong pro-environmental behavior in sustainabilityoriented courses.

While the actual content of the courses is not discussed here, the next step for this research is to measure attitudes after the course was competed to determine whether teaching certain environmental values had an effect on ecocentric evaluations. Reliability of the scale needs further testing, consequent research is necessary to improve institutional, national, and international applicability to particular cases.

It is unlikely, however, that the concrete outcomes of post-course evaluation 'measured' in well-defined units such as graded competencies and quantifiable skills will map neatly student ethical orientation, let along behavior. Understanding of the more challenging aspects of environmental sustainability is likely to develop after the information (cognitive aspects) has 'sunk in' and students' personal perceptions and affective attitudes have further evolved through continuous learning. This continuous learning is supported by both what students have learned in class and other formative events in their lives. These formative events for both Dutch and international students are likely to take place outside of the Netherlands, reflecting the increasing globalization of job markets in areas an diverse as business and anthropology. The Dutch higher education system provides a good backdrop for reflecting on how developed country students may be brought to think about 'environment' and 'development' elsewhere.

Examples of courses that are targeted to enhance ecocentric values include educational programs supporting animal rights and welfare, developed by the Animal Welfare Institute (AWI), and The International Fund for Animal Welfare (IFAW). Additionally, conservation education (e.g. Norris and Jacobson 1998; Goodall 2015), outdoor education (e.g. Sandell and Öhman 2010), animal-focused education (Spannring 2016), deep ecology education (e.g. Glasser 2004), and post-humanist education (e.g. Bonnett 2003) all promise to enhance ecocentric values. In the context of business education, as well as liberal arts, the author has reported a number of concrete programs aimed to enhance ecocentric values (Kopnina 2012a, Kopnina 2012b, Kopnina 2013; Kopnina and Blewitt 2014; Kopnina 2015; Kopnina 2016). Ongoing research by one of the authors is targeted at testing the efficacy of these programs in enhancing ecocentric orientations using both quantitative and qualitative methods. 


\title{
CONCLUSION
}

In this article we have hypothesized that students choosing for an elective course concerned with sustainability will be more ecocentric than those from a general business course. Comparative study has demonstrated that students who choose the elective sustainability courses exhibited ecocentric concerns in more or less equal measure as other business students. In sum, the analysis of EAATSD scale suggests that a) that while there are individual differences in attitudes between the students within the course, ecocentric orientations are present in all groups, independent of their chosen field of study; b) sustainability, at least prior to actually following the course, is not necessarily associated with environmental sustainability or higher environmental value orientations.

This suggests that ecocentric values are independent of the students' chosen course of study, but also that the self-selected students that chose sustainability course is not necessarily oriented toward environmental values. Considering that the studies have indicated that people with ecocentric orientation are more likely to act upon their values in order to protect the environment, this article proposes that courses need to be designed towards developing ecocetric values. Spannring (2016) has pointed out a number of ways in which nonhumans can be addressed in education. She states:

\begin{abstract}
Within an anthropocentric society the choice for a biocentric approach is bighly unlikely as long as this dominant paradigm is not deconstructed and linked to the environmental and animal ethical problems. So the call for a serious and sustained attention to anthropocentrism and speciesism is an invitation for our whole community of environmental education researchers to keep "moving [our own] margins" (Russell and Fawcett 2013 in Spanning 2016:12).
\end{abstract}

Indeed, this article fully supports this call.

\section{REFERENCES}

Baxter, B. (2005). A Theory of Ecological Justice. New York: Routledge.

Besong, F. and Holland, C. (2015). The Dispositions, Abilities and Behaviours: Framework for Profiling Learners' Sustainability Competencies in Higher Education. Journal of Teacher Education for Sustainability, 17(1), pp. 5-22.

Bonnett, M. (2003). Retrieving nature: Education for a post-humanist age. Journal of Pbilosophy of Education, 37(4), pp. 551-730.

Cafaro, P. (2015). Three ways to think about the sixth mass extinction. Biological Conservation, 192, pp. 387-393.

Cocks, S. and Simpson, S. (2015). Anthropocentric and Ecocentric: An Application of Environmental Philosophy to Outdoor Recreation and Environmental Education. Journal of Experiential Education, 1053825915571750.

Crist E. (2012). Abundant Earth and Population. In: P. Cafaro and E. Crist, ed., Life on the Brink: Environmentalists confront Overpopulation, Athens, GA: University of Georgia Press, pp. 141-153.

Dunlap, R.E. (2008). The New Environmental Paradigm Scale: From Marginality to Worldwide Use. The Journal of Environmental Education, 40(1), pp. 3-18.

Eckersley, R. (2004). The Green State: Retbinking Democracy and Sovereignty. MIT Press: London.

Gifford, R. (2011). The dragons of inaction: Psychological barriers that limit climate change mitigation and adaptation. American Psychologist, 66(4), pp. 290-302.

Glasser, H. (2004). Learning Our Way to a Sustainable and Desirable World: Ideas Inspired by Arne Naess and Deep Ecology. In: P.B. Corcoran and A.E.J. Wals, ed., Higher Education and the Challenge of Sustainability: Problematics, Promise, and Practice, pp. 131-148.

Gleeson, B. and Low, N. (eds.) (1999). Global Ethics and Environment. London, Routledge.

Goodall, J. (2015). Caring for People and Valuing Forests in Africa. In: G. Wuerthner, E. Crist and T. Butler, ed., Protecting the Wild: Parks and Wilderness, The Foundation for Conservation, Washington: The Island Press, pp. 21-26.

Hansen, A. and Wethal, U. (eds.) (2014). Emerging Economies and Challenges to Sustainability: Theories, strategies, local realities. New York: Routledge.

Kanyimba, A.T., Richter, B.W. and Raath, S.P. (2014). The effectiveness of an environmental management system in selected South African primary schools. Journal of Cleaner Production, 66, pp. 479-488.

Kaplan, S. (2000). Human Nature and Environmentally Responsible Behavior. Journal of Social Issues, 56(3), pp. 491-508.

Kopnina, H. (2012a). The Lorax Complex: Deep ecology, Ecocentrism and Exclusion. Journal of Integrative Environmental Sciences, 9(4), pp. 235-254.

Kopnina, H. (2012b). Education for Sustainable Development (ESD): The turn away from 'environment' in environmental education? Environmental Education Research, 18(5), pp. 699-717. 
Kopnina, H. (2013). Evaluating Education for Sustainable Development (ESD): Using Ecocentric and Anthropocentric Attitudes toward the Sustainable Development (EAATSD) scale. Environment, Development and Sustainability, 15(3), pp. 607-623.

Kopnina, H. (2015). Revisiting the Lorax complex: Deep ecology and biophilia in cross-cultural perspective. Environmental Sociology, 43(4), pp. 315-324.

Kopnina, H. (2016). The victims of unsustainability: A challenge to Sustainable Development Goals. International Journal of Sustainable Development \& World Ecology, 23(2), pp. 113-121.

Kopnina, H. and Blewitt, J. (2014). Sustainable Business: Key issues. Routledge Earthscan, New York.

Kortenkamp, K.V. and Moore, C.F. (2001). Ecocentrism and anthropocentrism: moral reasoning about ecological commons dilemmas. Journal of Environmental Psychology, 21, pp. 1-12.

Leopold, A. (1949). A S and County Almanac. Oxford: Oxford University Press.

Light, A. (1996). Compatibilism in political ecology. In: A. Light and E. Katz, ed., Environmental Pragmatism, New York: Routledge, pp. 161-184.

Miller, B., Soule, M. and Terborgh, J. (2013). 'The "New Conservation's" surrender to development', The Rewilding Institute, [online]. Available at: http://rewilding.org/rewildit/the-new-conservations-surrender-todevelopment/ [Accessed at 1 Jun. 2017]

Naess, A. (1973). The shallow and the deep: long-range ecology movement. A summary. Inquiry, 16(1), pp. 95-99.

Norris, K.S. and Jacobson, S.K. (1998). Content analysis of tropical conservation education programs: Elements of success. Journal of Environmental Education, 30(1), pp. 38-44.

Norton, B.G. (1984). Environmental Ethics and Weak Anthropocentrism, Environmental Ethics, 6(2), pp. 131-148.

Quinn, F., Castéra, J. and Clément, P. (2015). Teachers' conceptions of the environment: anthropocentrism, nonanthropocentrism, anthropomorphism and the place of nature. Environmental Education Research, 1-25.

Rees, W. (2010). What's blocking sustainability? Human nature, cognition, and denial. Sustainability: Science, Practice, and Policy, 6(2), pp. 13-25.

Rolston, H. III. (2015). Environmental Ethics for Tomorrow: Sustaining the Biosphere. In: H. Kopnina and E. Shoreman-Ouimet, ed., Sustainability: Key issues. New York: Routledge.

Sandell, K. and Öhman, J. (2010). Educational potentials of encounters with nature: Reflections from a Swedish outdoor perspective. Environmental Education Research, 16(1), pp. 113-32.

Shoreman-Ouimet, E. and Kopnina, H. (2016). Conservation and Culture: Beyond Anthropocentrism. New York: Routledge.

Singer, P. (1977). Animal Liberation: A New Ethics for our Treatment of Animals. New York: Random House.

Spannring, R. (2016). Animals in environmental education research. Environmental Education Research, 23(1), pp. 6374. doi:10.1080/13504622.2016.1188058

Stern, P.C. (2000). Toward a coherent theory of environmentally significant behaviour. Journal of Social Issues, 36, pp. 407-424.

Stern, P.C. and Dietz, T. (1994). The value basis of environmental concern. Journal of Social Issues, 50, pp. 65-84.

Thompson, G.S.C. and Barton, M.A. (1994). Ecocentric and anthropocentric attitudes toward the environment. Journal of Environmental Psychology, 14, pp. 149-157.

Vucetich, J.A. and Nelson, M.P. (2013). The Infirm Ethical Foundations of Conservation. In: M. Beckoff, ed., Ignoring Nature No More: The Case for Compassionate Conservation, Chicago: University of Chicago Press, pp. 9-25.

Washington, H. (2015). Demystifying Sustainability: Towards Real Solutions. New York: Routledge.

Wolbring, G. and Burke, B. (2013). Reflecting on education for sustainable development through two lenses: Ability studies and disability studies. Sustainability, 5(6), pp. 2327-2342. 


\section{APPENDICES}

\section{Mind Map}

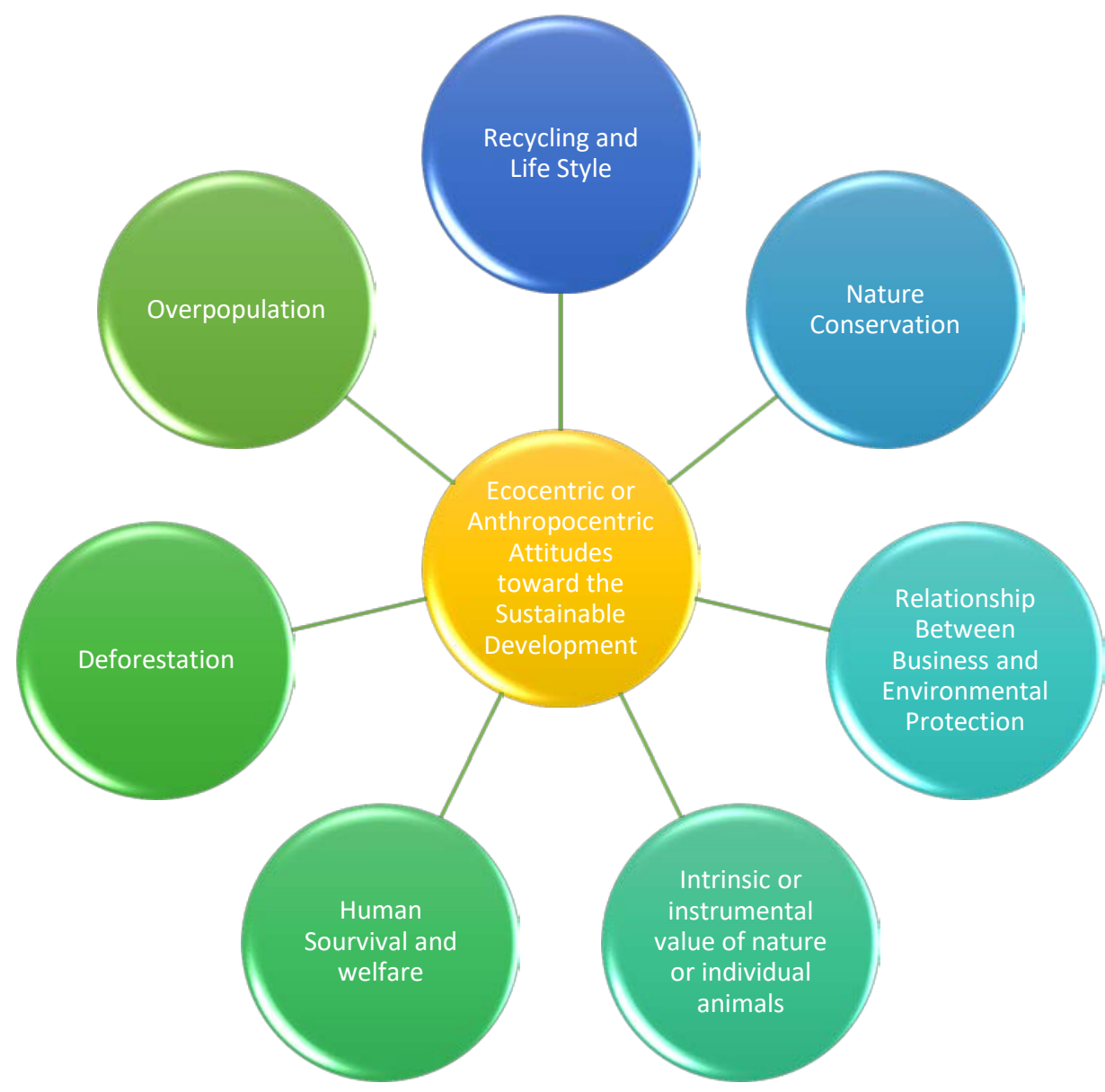




\section{The EAATSD Scale}

1. One of the worst things about overpopulation is that many natural areas are getting destroyed for development.

2. Environmental threats such as deforestation and ozone depletion have been exaggerated.

3. The worst thing about the loss of the rain forest is that it will restrict the development of new medicines and that there not be enough lumber for future generations.

4. It makes me sad to see forests cleared for agriculture.

5. It seems to me that most conservationists are pessimistic and somewhat paranoid.

6. I do not think the problem of depletion of natural resources is as bad as many people make it out to be.

7. I find it hard to get too concerned about environmental issues.

8. Humans are justified drilling for oil as it satisfies economic needs, even though it might be bad for the environment.

9. The thing that concerns me most about deforestation is that many species may be endangered by it.

10. I don't care about environmental problems.

11. The most important reason to keep lakes and rivers clean is so that people have drinking water.

12. It makes me sad to see natural environments destroyed.

13. The most important reason for conservation is human survival.

14. Best thing about recycling is that it saves money.

15. Nature is important because of what it can contribute to the pleasure and welfare of humans.

16. Too much emphasis has been placed on conservation.

17. Nature is valuable for its own sake, independent of human interests.

18. Nature conservation is important to ensure a continued high standard of living.

19. Nature conservation is important to preserve wild areas for plants and animals.

20. Continued land development is a good idea as long as a high quality of life can be preserved.

21. Animal testing should be prohibited even if this will slow the development of new medicines for humans.

22. Animal rights are as important as women rights, minority rights, gay rights and other equality issues. 


\section{SPSS}

The table below shows the average score of both sustainable business and other minor students. The cell of the table is shaded in light green to indicate ecocentric questions.

\begin{tabular}{|l|l|l|l|l|l|l|l|l|l|l|l|}
\hline & Q1 & Q2 & Q3 & Q4 & Q5 & Q6 & Q7 & Q8 & Q9 & Q10 & Q11 \\
\hline $\begin{array}{l}\text { average score for } \\
\text { sustainable business }\end{array}$ & 3.42 & 2.76 & 3.09 & 3.09 & 2.82 & 2.55 & 2.91 & 3.52 & 3.73 & 1.67 & 3.33 \\
\hline $\begin{array}{l}\text { average score for } \\
\text { other minors }\end{array}$ & 3.06 & 2.69 & 2.69 & 3.13 & 2.81 & 2.44 & 2.56 & 3.56 & 3.44 & 1.75 & 2.69 \\
\hline
\end{tabular}

\begin{tabular}{|l|l|l|l|l|l|l|l|l|l|l|l|}
\hline & Q12 & Q13 & Q14 & Q15 & Q16 & Q17 & Q18 & Q19 & Q20 & Q21 & Q22 \\
\hline $\begin{array}{l}\text { average score for } \\
\text { sustainable business }\end{array}$ & 4.00 & 3.21 & 2.67 & 3.91 & 2.94 & 3.45 & 3.79 & 3.91 & 3.39 & 3.06 & 3.09 \\
\hline $\begin{array}{l}\text { average score for } \\
\text { other minors }\end{array}$ & 3.69 & 3.63 & 2.88 & 3.44 & 2.69 & 2.75 & 3.75 & 4.00 & 3.38 & 3.19 & 3.44 \\
\hline
\end{tabular}

The table below is shows the average score, demonstrating that both sustainable business minor students and other minors students scale higher ecocentric than anthropocentric values.

\begin{tabular}{|l|l|l|}
\hline & Ecocentric & Anthropocentric \\
\hline average score for sustainable business & 3.47 & 3.04 \\
\hline average score for other minors & 3.34 & 2.92 \\
\hline
\end{tabular}

\section{Q2 vs. Q4}

\section{Crosstab}

Count

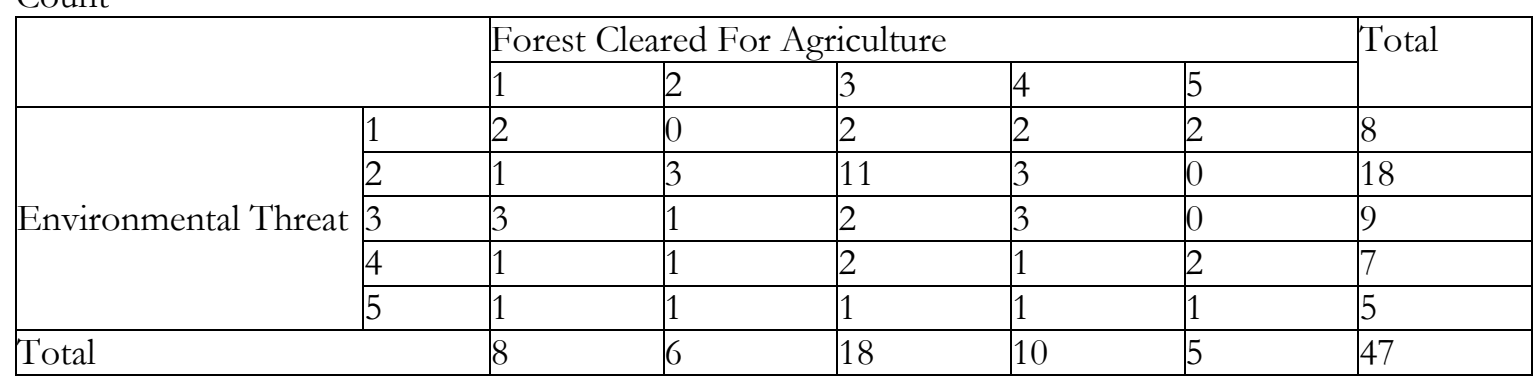

\section{Chi-Square Tests}

\begin{tabular}{|l|l|l|l|}
\hline & Value & df & Asymp. Sig. (2-sided) \\
\hline Pearson Chi-Square & $16.622^{\mathrm{a}}$ & 16 & .410 \\
\hline Likelihood Ratio & 19.259 & 16 & .255 \\
\hline $\begin{array}{l}\text { Linear-by-Linear } \\
\text { Association }\end{array}$ & .005 & 1 & .944 \\
\hline N of Valid Cases & 47 & & \\
\hline
\end{tabular}

a. 24 cells $(96.0 \%)$ have expected count less than 5 . The minimum expected count is .53 .

As the Chi-square tests shows, the correlation of question 2 and 4 (question 2 is anthropocentric, question 4 is ecocentric) is $41 \%$, meaning that there is no strong connection between them.

(We have an expected count of $96 \%$, therefore the assumptions have been violated, in this case we look at the likelihood ratio. The likelihood ratio needs to be smaller than 0.05 in order to have a dependence of the variables. The ratio is 0.255 in this case, therefore there is no correlation between the questions) 
Q6 vs. Q12

Natural Environments Destroyed * Problem of Depletion Cross tabulation

Count

\begin{tabular}{|c|c|c|c|c|c|c|c|}
\hline & \multicolumn{5}{|c|}{ Problem of Depletion } & \multirow[t]{2}{*}{ Total } \\
\hline & & 1 & 2 & 3 & 4 & 5 & \\
\hline \multirow{5}{*}{$\begin{array}{l}\text { Natural Environment } \\
\text { Destroyed }\end{array}$} & 1 & 0 & 1 & 2 & 0 & 0 & 3 \\
\hline & 2 & 0 & 0 & 0 & 2 & 0 & 2 \\
\hline & 3 & 3 & 2 & 3 & 1 & 0 & 9 \\
\hline & 4 & 4 & 10 & 4 & 0 & 0 & 18 \\
\hline & 5 & 2 & 8 & 2 & 2 & 2 & 16 \\
\hline Total & & 8 & 9 & 21 & 11 & 5 & 2 \\
\hline
\end{tabular}

\section{Chi-Square Tests}

\begin{tabular}{|l|l|l|l|}
\hline & Value & df & Asymp. Sig. (2-sided) \\
\hline Pearson Chi-Square & $30.845^{\mathrm{a}}$ & 16 & .014 \\
\hline Likelihood Ratio & 24.999 & 16 & .070 \\
\hline $\begin{array}{l}\text { Linear-by-Linear } \\
\text { Association }\end{array}$ & 218 & 1 & .641 \\
\hline N of Valid Cases & 48 & & \\
\hline
\end{tabular}

a. 23 cells $(92.0 \%)$ have expected count less than 5 . The minimum expected count is .08 .

The correlation of question 6 and 12 (question 6 is anthropocentric, question 12 is ecocentric) is $14 \%$.

(We have an expected count of $92 \%$, therefore the assumptions have been violated, in this case we look at the likelihood ratio. The likelihood ratio needs to be smaller than 0.05 in order to have a dependence of the variables. The ratio is 0.070 in this case, therefore there is no correlation between the questions. Although, the probability of having a correlation between this two questions is much higher than for other combinations of questions.)

\section{Q16 vs. Q19}

\section{Conservation * Plants and Animals Cross-tabulation}

Count

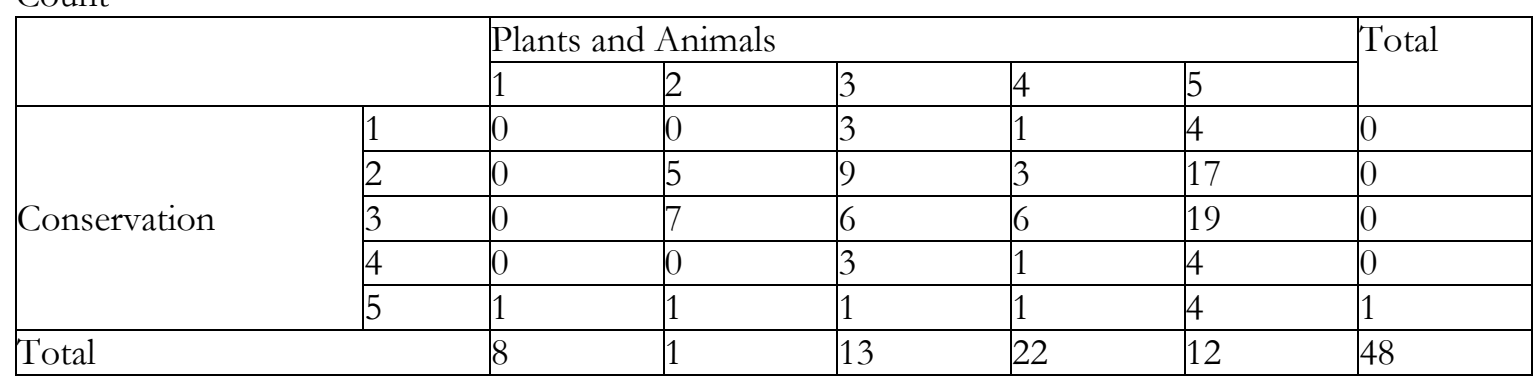

\section{Chi-Square Tests}

\begin{tabular}{|l|l|l|l|}
\hline & Value & df & Asymp. Sig. (2-sided) \\
\hline Pearson Chi-Square & $17.465^{\mathrm{a}}$ & 12 & .133 \\
\hline Likelihood Ratio & 13.478 & 12 & .335 \\
\hline $\begin{array}{l}\text { Linear-by-Linear } \\
\text { Association }\end{array}$ & 1.044 & 1 & .307 \\
\hline N of Valid Cases & 48 & & \\
\hline
\end{tabular}

a. 17 cells $(85.0 \%)$ have expected count less than 5 . The minimum expected count is .08 .

The correlation between question 16 and 19 (Question 16 is anthropocentric, question 19 is ecocentric) is $13.3 \%$. So there is no relationship for students answer in question 16 and 19.

(We have an expected count of $85 \%$, therefore the assumptions have been violated, in this case we look at the likelihood ratio. The likelihood ratio needs to be smaller than 0.05 in order to have a dependence of the variables. The ratio is 0.335 in this case, therefore there is no correlation between the questions). 


\section{Q3 vs. Q9}

Deforestation * Loss Of Rain Forrest Cross-tabulation

Count

\begin{tabular}{|c|c|c|c|c|c|c|c|}
\hline & \multicolumn{5}{|c|}{ Loss of Rain Forrest } & \multirow[t]{2}{*}{ Total } \\
\hline & & 1 & 2 & 3 & 4 & 5 & \\
\hline \multirow{5}{*}{ Deforestation } & 1 & 0 & 0 & 1 & 2 & 1 & 4 \\
\hline & 2 & 10 & 2 & 2 & 0 & 0 & 4 \\
\hline & 3 & 0 & 3 & 8 & 4 & 0 & 15 \\
\hline & 4 & 1 & 5 & 3 & 3 & 1 & 13 \\
\hline & 5 & 1 & 3 & 6 & 0 & 2 & 12 \\
\hline Total & & 8 & 2 & 13 & 20 & 9 & 4 \\
\hline
\end{tabular}

\section{Chi-Square Tests}

\begin{tabular}{|l|l|l|l|}
\hline & Value & df & Asymp. Sig. (2-sided) \\
\hline Pearson Chi-Square & $16.363^{\mathrm{a}}$ & 16 & .428 \\
\hline Likelihood Ratio & 21.370 & 16 & .165 \\
\hline $\begin{array}{l}\text { Linear-by-Linear } \\
\text { Association }\end{array}$ & 1.503 & 1 & .220 \\
\hline N of Valid Cases & 48 & & \\
\hline
\end{tabular}

a. 22 cells $(88.0 \%)$ have expected count less than 5 . The minimum expected count is .17 .

The correlation for question 3 and 9 (Question 3 is anthropocentric, question 9 is ecocentric) is $42.8 \%$.

(We have an expected count of $88 \%$, therefore the assumptions have been violated, in this case we look at the likelihood ratio. The likelihood ratio needs to be smaller than 0.05 in order to have a dependence of the variables. The ratio is 0.165 in this case, therefore there is no correlation between the questions). 
European Journal of Sociology and Anthropology, 2:1 (2017), 2

Group Statistics

\begin{tabular}{|c|c|c|c|c|c|}
\hline & Minar & $N$ & Mean & Std. Deviation & $\begin{array}{l}\text { Std. Error } \\
\text { Mean }\end{array}$ \\
\hline \multirow[t]{2}{*}{ EnvironmentalThreat } & Sustainable Business & 32 & 2,56 & 1,243 & .220 \\
\hline & Other Minor & 16 & 2,69 & 1,302 &, 326 \\
\hline \multirow[t]{2}{*}{ Overpopulation } & Sustainable Business & 33 & 3,42 & 1,173 & .204 \\
\hline & Other Minor & 16 & 3,06 & 1,124 &, 281 \\
\hline \multirow[t]{2}{*}{ LossofRainForrest } & Sustainable Business & 33 & 3,09 & 1,011 & .176 \\
\hline & Other Minor & 16 & 2,69 & 1,014 &, 254 \\
\hline \multirow{2}{*}{$\begin{array}{l}\text { ForestClearedFor } \\
\text { Agriculture }\end{array}$} & Sustainable Business & 33 & 3,09 & 1,128 & .196 \\
\hline & Other Minor & 15 & 2,73 & 1,387 &, 358 \\
\hline \multirow[t]{2}{*}{ Conservationists } & Sustainable Business & 32 & 2,63 & 1,070 & .189 \\
\hline & Other Minor & 16 & 2,81 & 1,047 &, 262 \\
\hline \multirow[t]{2}{*}{ ProblemofDepletion } & Sustainable Business & 32 & 2,34 & 1,125 & .199 \\
\hline & Other Minor & 16 & 2,44 &, 892 &, 223 \\
\hline \multirow[t]{2}{*}{ Envirormentallssues } & Sustainable Business & 32 & 2,72 & 1,276 & .226 \\
\hline & Other Minor & 16 & 2,56 & 1,094 & .273 \\
\hline \multirow[t]{2}{*}{ DrillingForOil } & Sustainable Business & 32 & 3,34 & 1,208 & .214 \\
\hline & Other Minor & 16 & 3,56 &, 964 & .241 \\
\hline \multirow[t]{2}{*}{ Deforestation } & Sustainable Business & 33 & 3,73 & 1,206 & .210 \\
\hline & Other Minor & 15 & 3,07 & 1,100 & .284 \\
\hline \multirow{2}{*}{$\begin{array}{l}\text { DontCareAbout } \\
\text { EnvironmentalProblems }\end{array}$} & Sustainable Business & 33 & 1,67 & 1,109 & .193 \\
\hline & Other Minor & 16 & 1,75 & 1,291 &, 323 \\
\hline \multirow[t]{2}{*}{ LakesAndriversClean } & Sustainable Business & 33 & 3,33 & 1,164 & ,203 \\
\hline & Other Minor & 16 & 2,69 & 1,195 & .299 \\
\hline \multirow{2}{*}{$\begin{array}{l}\text { NaturalEnvironments } \\
\text { Destroyed }\end{array}$} & Sustainable Business & 33 & 4,00 & 968 & .169 \\
\hline & Other Minor & 16 & 3,69 & 1,401 &, 350 \\
\hline \multirow[t]{2}{*}{ HumanSurvival } & Sustainable Business & 33 & 3,21 & 992 & .173 \\
\hline & Other Minor & 15 & 3,27 & 961 &, 248 \\
\hline \multirow[t]{2}{*}{ Recycling } & Sustainable Business & 33 & 2,67 & 1,164 & .203 \\
\hline & Other Minor & 16 & 2,88 & 1,258 &, 315 \\
\hline \multirow[t]{2}{*}{ ContributeToHumans } & Sustainable Business & 33 & 3,91 & 879 & .153 \\
\hline & Other Minor & 16 & 3,44 & 629 & .157 \\
\hline \multirow[t]{2}{*}{ Conservation } & Sustainable Business & 33 & 2,94 & .966 & .168 \\
\hline & Other Minor & 15 & 2,27 & 1,033 & 267 \\
\hline \multirow[t]{2}{*}{ ValuableForltsownSake } & Sustainable Business & 32 & 3,28 & 1,301 & .230 \\
\hline & Other Minor & 16 & 2,75 & 1,065 & .266 \\
\hline \multirow[t]{2}{*}{ HighStandardsOfLiving } & Sustainable Business & 33 & 3,79 & 1,053 & .183 \\
\hline & Other Minor & 16 & 3,75 &, 931 & .233 \\
\hline \multirow[t]{2}{*}{ PlantsAndAnimals } & Sustainable Business & 33 & 3,91 & 947 & .165 \\
\hline & Other Minor & 16 & 4,00 & .632 & .158 \\
\hline \multirow[t]{2}{*}{ LandDevelopment } & Sustainable Business & 33 & 3,39 &, 998 & .174 \\
\hline & Other Minor & 16 & 3,38 & 1,025 &, 256 \\
\hline \multirow[t]{2}{*}{ AnimalTesting } & Sustainable Business & 33 & 3,06 & 1,029 & .179 \\
\hline & Other Minor & 16 & 3,19 & 1,377 &, 344 \\
\hline \multirow[t]{2}{*}{ AnimalRights } & Sustainable Business & 33 & 3,09 & 1,128 & .196 \\
\hline & Other Minor & 16 & 3,44 & 1,365 & .341 \\
\hline
\end{tabular}




\section{STUDY}

\begin{tabular}{|c|c|c|c|c|c|c|c|c|c|}
\hline \multicolumn{10}{|c|}{ Keport } \\
\hline & \multicolumn{9}{|c|}{ Minor } \\
\hline & \multicolumn{3}{|c|}{ E\&D } & \multicolumn{3}{|c|}{ BE\&S } & \multicolumn{3}{|c|}{ Total } \\
\hline & Mean & $\mathrm{N}$ & Std. Deviation & Mean & $\mathrm{N}$ & Std. Deviation & Mean & $\mathrm{N}$ & Std. Deviation \\
\hline EAATSD1 & 3,9444 & 18 &, 93760 & 3,7619 & 42 & ,90553 & 3,8167 & 60 & 91117 \\
\hline EAATSD2 & 1,1667 & 18 &, 38348 & 2,3333 & 42 & 1,05152 & 1,9833 & 60 & 1,04948 \\
\hline EAATSD3 & 2,2778 & 18 &, 89479 & 3,0476 & 42 & 1,08093 & 2,8167 & 60 & 1,08130 \\
\hline EAATSD 4 & 3,8889 & 18 &, 67640 & 3,3333 & 42 & ,92833 & 3,5000 & 60 & .89253 \\
\hline EAATSD5 & 2,0588 & 17 & 1,34493 & 2,6341 & 41 &, 88758 & 2,4655 & 58 & 1,06319 \\
\hline EAATSD6 & 1,3529 & 17 & ,86177 & 1,9286 & 42 &, 89423 & 1,7627 & 59 &, 91612 \\
\hline EAATSD7 & 1,7778 & 18 & 1,16597 & 2,5714 & 42 &, 85946 & 2,3333 & 60 & 1,01958 \\
\hline EAATSD 8 & 2,2778 & 18 & 1,36363 & 3,0000 & 42 &, 85540 & 2,7833 & 60 & 1,07501 \\
\hline EAATSD 9 & 3,5556 & 18 &, 98352 & 3,5750 & 40 & 1,10680 & 3,5690 & 58 & 1,06148 \\
\hline EAATSD10 & 1,1667 & 18 & ,38348 & 1,4048 & 42 &, 58683 & 1,3333 & 60 &, 54202 \\
\hline EAATSD11 & 2,7778 & 18 & 1,21537 & 3,3333 & 42 & 1,07446 & 3,1667 & 60 & 1,13745 \\
\hline EAATSD12 & 4,1667 & 18 & 1,20049 & 3,7143 & 42 & 1,17465 & 3,8500 & 60 & 1,19071 \\
\hline EAATSD13 & 3,0556 & 18 &, 93760 & 3,2857 & 42 &, 96993 & 3,2167 & 60 & ,95831 \\
\hline EAATSD14 & 2,2778 & 18 &, 75190 & 2,6190 & 42 & 1,03482 & 2,5167 & 60 &, 96536 \\
\hline EAATSD15 & 3,5000 & 18 &, 70711 & 3,6429 & 42 & 1,05510 & 3,6000 & 60 &, 96023 \\
\hline EAATSD16 & 1,9444 & 18 &, 72536 & 2,5238 & 42 &, 63392 & 2,3500 & 60 & ,70890 \\
\hline EAATSD17 & 4,2778 & 18 &, 82644 & 3,5952 & 42 & 1,14890 & 3,8000 & 60 & 1,10162 \\
\hline EAATSD18 & 3,0556 & 18 & 1,10997 & 3,3659 & 41 & 1,01873 & 3,2712 & 59 & 1,04767 \\
\hline EAATSD19 & 4,0000 & 18 &, 90749 & 3,7381 & 42 &, 88509 & 3,8167 & 60 & 89237 \\
\hline EAATSD20 & 2,4444 & 18 &, 92178 & 3,4762 & 42 & 1,01784 & 3,1667 & 60 & 1,09183 \\
\hline EAATSD21 & 2,5556 & 18 & 1,14903 & 2,6905 & 42 & 1,19935 & 2,6500 & 60 & 1,17639 \\
\hline EAATSD22 & 2,9444 & 18 & 1,05564 & 3,0952 & 42 & 1,37592 & 3,0500 & 60 & 1,28122 \\
\hline
\end{tabular}

EAATSD2 * EAATSD4 Crosstabulation

\begin{tabular}{|c|c|c|c|c|c|c|c|}
\hline & & \multicolumn{5}{|c|}{ EAATSD4 } & \multirow[t]{2}{*}{ Total } \\
\hline & & $\begin{array}{l}\text { Strongly } \\
\text { Disagree }\end{array}$ & 2,00 & 3,00 & 4,00 & Strongly Agree & \\
\hline \multirow{5}{*}{ EAATSD2 } & Strongly Disagree & 0 & 2 & 6 & 13 & 4 & 25 \\
\hline & 2,00 & 0 & 2 & 10 & 3 & 3 & 18 \\
\hline & 3,00 & 1 & 2 & 3 & 5 & 0 & 11 \\
\hline & 4,00 & 0 & 0 & 2 & 3 & 0 & 5 \\
\hline & Strongly Agree & 0 & 0 & 1 & 0 & 0 & 1 \\
\hline Total & & 1 & 6 & 22 & 24 & 7 & 60 \\
\hline
\end{tabular}

\section{Chi-Square Tests}

\begin{tabular}{|l|r|r|r|}
\hline & \multicolumn{1}{|c|}{ Value } & df & $\begin{array}{c}\text { Asymp. Sig. (2- } \\
\text { sided) }\end{array}$ \\
\hline Pearson Chi-Square & $17,236^{\mathrm{a}}$ & 16 &, 371 \\
Likelihood Ratio & 19,063 & 16 &, 265 \\
Linear-by-Linear & 2,555 & 1 &, 110 \\
Association & 60 & & \\
N of Valid Cases & & & \\
\hline
\end{tabular}

a. 21 cells $(84.0 \%)$ have expected count less than 5 . The minimum expected count is 02 .

(We have an expected count of $84 \%$, therefore the assumptions have been violated, in this case we look at the likelihood ratio. The likelihood ratio needs to be smaller than 0.05 in order to have a dependence of the variables. The ratio is 0.265 in this case, therefore there is no correlation between the questions.) 
EAATSD6 * EAATSD12 Crosstabulation

\begin{tabular}{|c|c|c|c|c|c|c|c|}
\hline & & \multicolumn{5}{|c|}{ EAATSD12 } & \multirow[t]{2}{*}{ Total } \\
\hline & & $\begin{array}{l}\text { Strongly } \\
\text { Disagree }\end{array}$ & 2,00 & 3,00 & 4,00 & Strongly Agree & \\
\hline \multirow{4}{*}{ EAATSD6 } & Strongly Disagree & 2 & 2 & 5 & 6 & 15 & 30 \\
\hline & 2,00 & 2 & 1 & 4 & 5 & 4 & 16 \\
\hline & 3,00 & 0 & 0 & 1 & 6 & 3 & 10 \\
\hline & 4,00 & 0 & 1 & 0 & 2 & 0 & 3 \\
\hline Total & & 4 & 4 & 10 & 19 & 22 & 59 \\
\hline
\end{tabular}

\section{Chi-Square Tests}

\begin{tabular}{|l|r|r|r|}
\hline & \multicolumn{1}{|c|}{ Value } & \multicolumn{1}{c|}{$\mathrm{df}$} & $\begin{array}{c}\text { Assmp. Sig. (2- } \\
\text { sided) }\end{array}$ \\
\hline Pearson Chi-Square & $14,973^{\mathrm{a}}$ & 12 &, 243 \\
Likelihood Ratio & 15,880 & 12 &, 197 \\
Linear-by-Linear &, 218 & 1 &, 640 \\
Association & 59 & & \\
N of Valid Cases & & & \\
\hline
\end{tabular}

a. 15 cells $(75,0 \%)$ have expected count less than 5 . The minimum expected count is. 20 .

(We have an expected count of 75\%, therefore the assumptions have been violated, in this case we look at the likelihood ratio. The likelihood ratio needs to be smaller than 0.05 in order to have a dependence of the variables. The ratio is 0.197 in this case, therefore there is no correlation between the questions.)

EAATSD16 * EAATSD19 Crosstabulation

\begin{tabular}{|c|c|c|c|c|c|c|c|}
\hline & & \multicolumn{5}{|c|}{ EAATSD19 } & \multirow{2}{*}{ Total } \\
\hline & & $\begin{array}{l}\text { Strongly } \\
\text { Disagree }\end{array}$ & 2,00 & 3,00 & 4,00 & Strongly Agree & \\
\hline \multirow{4}{*}{ EAATSD16 } & Strongly Disagree & 0 & 0 & 1 & 0 & 6 & 7 \\
\hline & 2,00 & 0 & 1 & 9 & 11 & 5 & 26 \\
\hline & 3,00 & 1 & 2 & 5 & 16 & 2 & 26 \\
\hline & 4,00 & 0 & 0 & 0 & 1 & 0 & 1 \\
\hline Total & & 1 & 3 & 15 & 28 & 13 & 60 \\
\hline
\end{tabular}

\begin{tabular}{|c|c|c|c|}
\hline \multicolumn{4}{|c|}{ Chi-Square Tests } \\
\hline & Value & $\mathrm{df}$ & $\begin{array}{c}\text { Asymp. Sig. (2- } \\
\text { sided) }\end{array}$ \\
\hline Pearson Chi-Square & $25,131^{\mathrm{a}}$ & 12 &, 014 \\
\hline Likelihood Ratio & 24,373 & 12 & ,018 \\
\hline Linear-by-Linear & & & \\
\hline Association & 5,265 & 1 & ,022 \\
\hline $\mathrm{N}$ of Valid Cases & 60 & & \\
\hline
\end{tabular}

a. 14 cells $(70,0 \%)$ have expected count less than 5 . The minimum expected count is, 02 .

We have an expected count of $70 \%$, therefore the assumptions have been violated, in this case we look at the likelihood ratio. The likelihood ratio needs to be smaller than 0.05 in order to have a dependence of the variables. The ratio is 0.018 in this case, therefore there is a correlation between the questions.) 
$\Psi$

EAATSD $3{ }^{*}$ EAATSD9 Crosstabulation

\begin{tabular}{|c|c|c|c|c|c|c|c|}
\hline \\
\hline & & \multicolumn{5}{|c|}{ EAATSD 9} & \multirow[t]{2}{*}{ Total } \\
\hline & & $\begin{array}{l}\text { Strongly } \\
\text { Disagree }\end{array}$ & 2,00 & 3,00 & 4,00 & Strongly Agree & \\
\hline \multirow{5}{*}{ EAATSD3 } & Strongly Disagree & 0 & 2 & 1 & 1 & 1 & 5 \\
\hline & 2,00 & 0 & 2 & 4 & 11 & 4 & 21 \\
\hline & 3,00 & 0 & 7 & 2 & 9 & 0 & 18 \\
\hline & 4,00 & 1 & 0 & 0 & 5 & 3 & 9 \\
\hline & Strongly Agree & 0 & 1 & 1 & 1 & 2 & 5 \\
\hline Total & & 1 & 12 & 8 & 27 & 10 & 58 \\
\hline
\end{tabular}

\section{Chi-Square Tests}

\begin{tabular}{|l|r|r|r|}
\hline & \multicolumn{1}{|c|}{ Value } & \multicolumn{1}{|c|}{$\mathrm{df}$} & $\begin{array}{c}\text { Assmp. Sig. (2- } \\
\text { sided) }\end{array}$ \\
\hline Pearson Chi-Square & $22,280^{\mathrm{a}}$ & 16 &, 134 \\
Likelihood Ratio & 25,917 & 16 &, 055 \\
Linear-by-Linear &, 306 & 1 &, 580 \\
Association & 58 & & \\
N of Valid Cases & & & \\
\hline
\end{tabular}

a. 23 cells $(92.0 \%)$ have expected count less than 5 . The minimum expected count is, 09 .

(We have an expected count of $92 \%$, therefore the assumptions have been violated, in this case we look at the likelihood ratio. The likelihood ratio needs to be smaller than 0.05 in order to have a dependence of the variables. The ratio is 0.055 in this case, therefore there is no correlation between the questions. Although, the probability of having a correlation between this two questions is much higher than for other combinations of questions.) 